\title{
Parameters of the Histological Adaptation of Marmorkrebs Procambarus virginalis (Lyko, 2017) (Decapoda, Cambaridae) to Manganese, Nickel and Lead lons Pollution
}

\author{
Alexandra Naboka*, Oleh Marenkov, Julia Kovalchuk, Zoya Shapovalenko, \\ Oleh Nesterenko, Bogdan Dzhobolda
}

Oles Honchar Dnipro National University, Research Institute of Biology, Research Laboratory of Hydrobiology, Ichthyology and Radiobiology, P.M.B. 49050, Dnipro, Ukraine

*hydrodnu@gmail.com

Keywords: Procambarus virginalis, glandulocytes, hepatopancreas, hemolymph, manganese, nickel, lead, crustaceans.

\begin{abstract}
Manganese, lead and nickel are heavy metals, which are the primary fresh water toxic contaminants being in the most dangerous class of chemicals. Heavy metals cause functional disorders in the tissues and organs of hydrobionts, affecting their linear and weight indices, reproductive system, digestive and extraction organs. In our experiment on marbled crayfish Procambarus virginalis (Lyko, 2017) we studied the long-term effects of various concentrations of heavy metal ions on the physiological state and histostructure of tissues and organs. According to the results of research, it was found that among the studied heavy metals nickel ions influenced the weight indexes and mortality of crustaceans the most negatively. The results of morphometric studies on marbled crayfish indicate no significant differences between the control group and experimental one, but heavy metals influenced the form of the hepatopancerase lobes and the size of the lumen of the gland. Research on adipocytes of the connective tissue showed a significant difference between the size of cells under the influence of heavy metals. Dimensions of adipocytes fluctuated over a wide range from $144 \mu \mathrm{m}^{2}$ to $537 \mu \mathrm{m}^{2}$. In control group the adipocyte area was $406.96 \mathrm{\mu m}^{2}$. Experimental studies of hemolymph showed that, under the influence of lead ions, a significant 1.4 times increase was observed in the area of hemolymph cells; when manganese and nickel were added, moderate decrease was observed in cells. It was found that under the influence of nickel, the area of round hyalinocytes has reduced by 1.7 times.
\end{abstract}

\section{Introduction}

On the territory of Ukraine, marbled crayfish are freely available in pet stores, in pet markets and online resources. In most cases, the cost of one individual does not exceed 1 euro, and even more often young crustaceans are free of charge, because of the rapid reproduction of these crayfish create problems for aquarists. A number of researchers have studied the risks of introduction of marbled crayfish into the natural reservoirs of Ukraine [1]. They claim that the climatic conditions of the reservoirs of the central and southern parts of Ukraine are perfectly suitable for the naturalization of marbled crayfish and classify marbled crayfish as a species with a high level of invasiveness $[1,2]$.

Marbled crayfish are now occasionally found in the reservoirs of Ukraine, which confirms the expected risks of its introduction and naturalization $[1,3,4]$. High ecological plasticity and the ability for parthenogenetic reproduction allow marble crayfish to rapidly increase the number in recipient reservoirs and adapt to their conditions. Adaptation of crustaceans to habitat conditions (temperature and hydrochemical regime, anthropogenic factors, etc.) occurs at the biochemical and cellular level, which allows crayfish adapting to living in water bodies with a high level of toxicological contamination [5].

Based on the above, there is a scientific interest in studying the adaptive mechanisms of marbled crayfish under conditions of toxicological contamination of water bodies under the influence of heavy metals [6]. 
Therefore, the purpose of our work was to determine the influence of heavy metal ions on the morphological and physiological state and the histological structure of some connective tissues of marbled crayfish.

Recently anthropogenic influence on natural complexes, especially water ecosystems of urbanized territories of Ukraine, has considerably intensified [7]. The increased anthropogenic pollution of surface water resulted in a violation of the ecological balance. The speed of successive changes in aquatic ecosystems has significantly increased. Moreover, heavy metals are serious toxic pollutants that can be transported along with water masses over long distances. Heavy metals are extremely hazardous as pollutants of natural waters, which, even at relatively low concentrations, can negatively affect aquatic organisms, including freshwater crayfish. The major pollutants in the Dnipro region are ions of heavy metals: nickel, lead, cadmium, iron, aluminum, manganese, zinc and copper. Long-term scientific research has shown that in the water of the Zaporizhzhya (Dnipro) reservoir and its inflow there is a continuous violation of the SanPin-88 regulatory requirements for the content of $\mathrm{Cd}, \mathrm{Mn}, \mathrm{Cu}$ and, in some areas, for the content of $\mathrm{Zn}, \mathrm{Ni}$ and $\mathrm{Fe}[8,9]$. These heavy metals can reduce the number, suppress development and cause the death of hydrobionts sensitive to the action of toxicants [10].

Lead is one of the most toxic and dangerous heavy metals. As an extremely toxic substance in the environment, it is included in the list of priority pollutants by a number of international organizations, including UNEP and the European Economic Commission. The American Agency for Toxic Substances and Disease Registry (ATSDR) is collecting and analysing the information on lead neurotoxic activity, delivering results directly to the US Senate. In many countries of the world (the USA, Germany, Denmark, Australia, Mexico, Thailand, etc.) national programs are developed to reduce the pollution of the environment by lead and limit its negative impact on public health [11].

In aqueous systems, lead is mainly adsorbed, bound to suspended particles, or it is in the form of soluble complexes with humic acids. In non-contaminated surface waters of land, the lead content usually does not exceed $3 \mu \mathrm{g} /$ liter. In the rivers of industrial regions there is a higher content of lead $[12,13]$.

Since 1994 there is a weak tendency to increasing concentration of lead in the water of Zaporizhzhya (Dnipro) reservoir from 0.0026 to $0.0035 \mathrm{mg} / 1$ [14]. In recent years, an increase in lead concentration has been observed of almost 4 times compared with previous studies. The average annual lead content for the period from 2004 to 2007 in the Zaporizhzhya (Dnipro) reservoir water area is at the same level and reaches $0.015 \mathrm{mg} / \mathrm{l}$ and does not exceed the MAC for fishery reservoirs and reservoirs of cultural and household purposes [7].

Among the Dnipro reservoirs Zaporizhzhya (Dnipro) reservoir is characterized by the smallest content of manganese dissolved in water, because of the peculiarities of the hydrological and hydrochemical regime of the reservoir [15]. Manganese in surface water comes from the leaching of iron ore and other minerals containing manganese. A significant amount of manganese comes because of the decomposition of aquatic animal and plant organisms, primarily blue-green algae, diatom algae and higher aquatic plants. Manganese compounds are deposited in the reservoirs with sewage from manganese concentrating factories, metallurgical plants, chemical industry enterprises and mine waters [7].

Reduction of concentration of manganese ions in natural waters is caused by the oxidation of $\mathrm{Mn}$ (II) to $\mathrm{MnO}_{2}$ and other high-valency oxides that precipitate. The main parameters that determine the oxidation reaction are the concentration of dissolved oxygen, $\mathrm{pH}$ and temperature. The concentration of dissolved compounds of manganese is reduced due to their disposal by algae [7].

According to the staff of the Department of General Biology and Water Bioresources and the Research Institute of Biology of the Oles Honchar DNU, there is a weak tendency to reduce the content of manganese in the water of the Zaporizhzhya (Dnipro) reservoir from 1969 to 1999 from $0.033 \mathrm{mg} / 1$ to $0.025 \mathrm{mg} / 1$ [16]. The same trend has been observed in recent years. The content of manganese in the water of the Samara Bay decreased to $0.02 \mathrm{mg} / \mathrm{l}$, and up to $0.0067 \mathrm{mg} / \mathrm{l}$ in the 
water of the lower part of the reservoir. The average annual concentration of manganese in the water of the Samara region exceeds twice the fishery's MAC [7].

The nickel in natural waters appears because of the composition of rocks through which water passes: it is detected in deposits of sulfide copper-nickel and iron-nickel ores. It gets to the water from soils and from plant and animal organisms at their decomposition. Nickel compounds also come in water bodies from sewage from the shops of nickel, synthetic rubber plants, nickel concentrating factories $[7,9]$.

In surface waters, nickel compounds are in a dissolved, weighed and colloidal state, and the quantitative relation depends on the composition of water, temperature and $\mathrm{pH}$ values. Dissolved forms are mainly complex ions, most often with amino acids, humic and fulvic acids, as well as in the form of a strong cyanide complex [7].

Nickel compounds play an important role as catalysts in hematopoiesis. Its elevated content specifically affects the circulatory and nervous system. Nickel is one of the carcinogenic elements. It is able to cause epithelial tissue disease. It is considered that free ions of nickel are approximately 2 times more toxic than its complex compounds [7,9].

Research of nickel content in the hydroelectric system of the Zaporizhzhya (Dnipro) reservoir began in 1986. During the years of research, an increase was observed in the concentration of nickel in the water of the Zaporizhzhya (Dnipro) reservoir. From 1986 to 1999 its content gradually increased by $22 \%$, from 0.0018 to $0.0022 \mathrm{mg} / 1$ [16]. In recent years, the average concentration of nickel in the Samara Bay has increased 18 times, and in the lower part of the reservoir almost fourfold compared with previous studies. The content of nickel in the water of the Samara Bay exceeds the fishing MAC on average by 4 times $[7,9]$.

The biological effects of heavy metal contamination of the aquatic environment are manifested, first of all, in direct toxic effects on hydrobionts, which leads to the defeat of their physiological systems.

\section{Materials and Methods}

We conducted a laboratory model experiments to study the mechanisms of adaptation of marbled crayfish Procambarus virginalis (Lyko, 2017). The influence of heavy metal ions on the enzymatic activity of marbled crayfish of marmorkrebs was determined. The experiment was conducted in 4 aquariums with working capacity of 30 liters. The water temperature was maintained by thermostat and was $+22^{\circ} \mathrm{C}$. Oxygen regime was maintained by the compressor, the oxygen content in the water of aquariums was $6-7 \mathrm{mg} / 1$. To avoid the incidence of cannibalism in aquariums, we set special shelters made from chemically neutral material for marbled crayfish. Water in aquariums was completely changed twice a week and toxicants were added at the rate of concentrations of metal ions: $\mathrm{Ni}^{2+}-0.04 \mathrm{mg} / 1$ (4 MAC), $\mathrm{Pb}^{2+}-0.15 \mathrm{mg} / \mathrm{l}$ (1.5 MAC), $\mathrm{Mn}^{2+}-0.02 \mathrm{mg} / \mathrm{l}(2 \mathrm{MAC})$. Concentrations of heavy metals were determined by their content in water of Zaporizhzhya (Dnipro) reservoir, the main recipient reservoir for this species. Crayfish were fed every day with the same quantity of food. In each aquarium there were 15 parthenogenetic individuals of the marbled crayfish with the same size and age group from one female. The experiment lasted 21 days.

The influence of heavy metal ions on the growth of marbled crayfish were evaluated using morphometric measurements of crustaceans. Measurements of crayfish were performed by a ruler and a digital caliper according to the developed scheme (Fig. 1). 


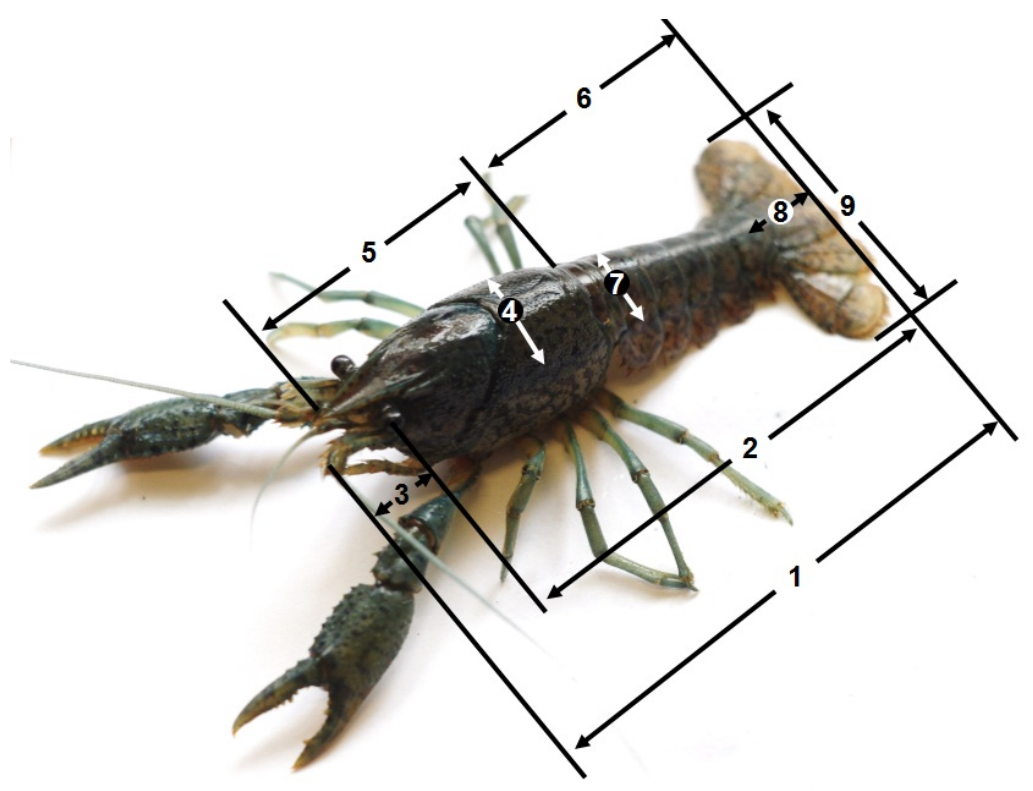

Figure 1. Marmorkrebs measurements: 1 - full length; 2 - industrial length; 3 - length of rostrum; 4 - width of the cephalothorax; 5 - the length of the cephalothorax; 6 - length of the abdomen; 7 width of the abdomen at the beginning of the $3^{\text {rd }}$ segment; 8 - length of telson; 9 - width of telson

Hemolymph of marbled crayfish was taken from the heart through the insulin syringe (Fig. 2). The crayfish were fixed on a surface, hemolymph was taken from the heart and subjected to a smear on the oblique glass. Hemolymphs was stained by azur-eosin by the Romanovsky-Gimse with some modifications.

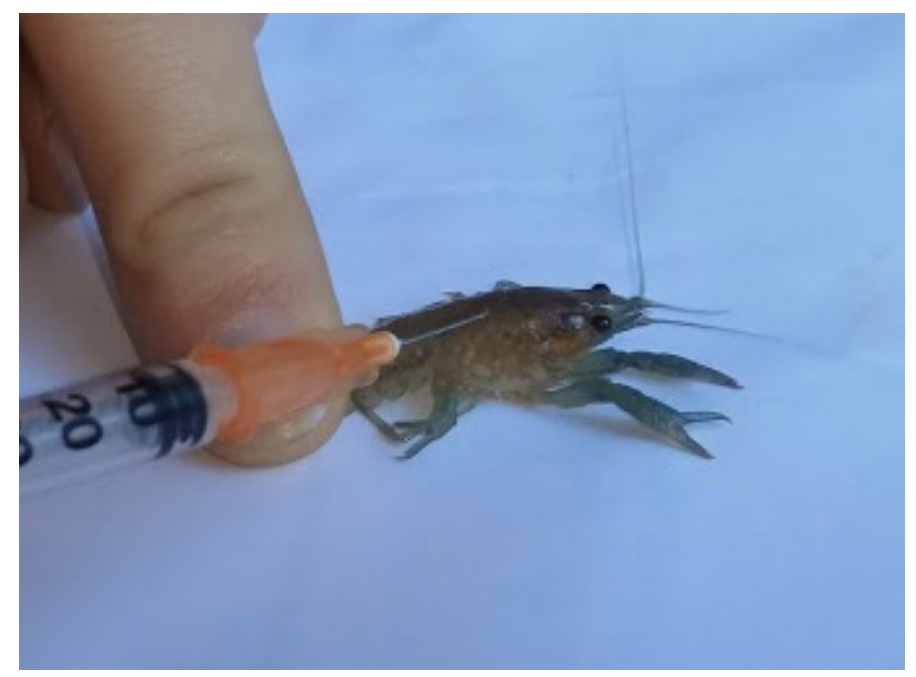

Figure 2. Intra vital method of selecting hemolymph from the heart of marbled crayfish

To investigate the impact of heavy metals on histological structure of tissues and organs of marbled crayfish histological research methods were used. Individuals of control and experimental groups at the end of the experiment were fixed in $4 \%$ formalin solution, followed by processing by conventional histological methods. To produce slices microtome MC-2 was used. Histological sections were stained using haematoxylin-eosin. Photographs of preparations were made by a digital microscope attachment «Sciencelab T500 5.17 M», which was connected to a microscope Jenaval. Histological preparations were described using histology atlases of crustaceans [17].

During the work, bioethical norms are not violated. The experiment was performed according to the "Provisions for the use of animals in biomedical experiments" [18].

Statistical data processing was carried out by conventional methods using software packages for personal computers Statistica 8.0 (StatSoftInc, USA). All results are given as the mean \pm 
standard deviation (SD). There liability of the difference between data samples was determined using one-factor ANOVA dispersion analysis at a significance level $p<0.05, p<0.01, p<0.001$.

\section{Results and Discussion}

Effect of heavy metals on morphometric indices and body weight. At the beginning of the experiment, all marbled crayfish had an average weight of individuals $0.67 \mathrm{~g}$, that is, they belonged to a same dimensional group. Compared with the beginning of the experiment, marbled crayfish in the control group, in experiment with manganese and in the experiment with lead increased their mass by $40.9-66.1 \%$. At the end of the experiment, the mass gain in the control aquarium was $0.43 \mathrm{~g}(60.6 \%)$. The largest increase in the mass of marbled crayfish was observed in a test with lead $-0.45 \mathrm{~g}(66.1 \%)$. At the end of the experiment, the statistically significant difference between the mass of crustaceans was observed between control group and experiment with nickel, the crayfish did not grow during the experiment, and even lost weight, by an average of $3.3 \%$ compared with the beginning of the experiment. Thus, among the studied heavy metals, nickel ions affected the weight indexes of crustaceans most negatively.

The total length of the crayfish ranged from 3.32 to $3.58 \mathrm{~cm}$ and averaged $3.43 \mathrm{~cm}$. The variation in the length of marbled crayfish ranged from $3 \%$ to $9 \%$, and the figures did not differ statistically (Table 1).

Table 1. Results of morphometric studies of marbled crayfish at the end of the experiment

\begin{tabular}{|l|c|c|c|c|}
\hline \multicolumn{1}{|c|}{ Parameters, cm } & Control & $\begin{array}{c}\text { Experiment } \\
\text { with Ni }\end{array}$ & $\begin{array}{c}\text { Experiment } \\
\text { with } \mathrm{Pb}\end{array}$ & $\begin{array}{c}\text { Experiment } \\
\text { with } \mathrm{Mn}\end{array}$ \\
\hline Full length & $3.58 \pm 0.44$ & $3.23 \pm 0.25$ & $3.46 \pm 0.39$ & $3.46 \pm 0.17$ \\
\hline Industrial length & $3.19 \pm 0.35$ & $2.85 \pm 0.26$ & $2.98 \pm 0.43$ & $3.11 \pm 0.47$ \\
\hline Length of rostrum & $0.42 \pm 0.12$ & $0.38 \pm 0.04$ & $0.40 \pm 0.08$ & $0.36 \pm 0,13$ \\
\hline Width of the cephalothorax & $0.61 \pm 0.14$ & $0.56 \pm 0.07$ & $0.59 \pm 0.11$ & $0.51 \pm 0.09$ \\
\hline The length of the cephalothorax & $1.69 \pm 0.31$ & $1.53 \pm 0.14$ & $1.70 \pm 0.26$ & $1.68 \pm 0.17$ \\
\hline Length of the abdomen & $1.87 \pm 0.24$ & $1.70 \pm 0.17$ & $1.76 \pm 0.26$ & $1.78 \pm 0.41$ \\
\hline $\begin{array}{l}\text { Width of the abdomen at the } \\
\text { beginning of the } 3^{\text {rd }} \text { segment }\end{array}$ & $0.54 \pm 0.10$ & $0.50 \pm 0.06$ & $0.49 \pm 0.08$ & $0.50 \pm 0.09$ \\
\hline Length of telson & $0.53 \pm 0.07$ & $0.55 \pm 0.05$ & $0.51 \pm 0.05$ & $0.51 \pm 0.08$ \\
\hline Width of telson & $1.48 \pm 0.36$ & $1.12 \pm 0.15$ & $1.39 \pm 0.25$ & $1.44 \pm 0.24$ \\
\hline
\end{tabular}

Physiological evaluation of hepatopancreas under the influence of heavy metals. In control, the cross-sectional area of the hepatopancreas was $3856.59 \mu \mathrm{m}^{2}$ with a lumen of $1155.62 \mu \mathrm{m}^{2}$. In the experiment with nickel no significant difference was observed. The cross-sectional area of the hepatopancreas was $3698.9 \mu \mathrm{m}^{2}$ with a lumen of $1046.93 \mu \mathrm{m}^{2}$. In the experiment with manganese and lead, the hepatopancreas were reduced by $14.79 \%$ and $2.89 \%$ respectively (Table 2 ).

Table 2. Histometric parameters of hepatopancreas $(n=50, x \pm S D)$

\begin{tabular}{|l|c|c|c|c|}
\hline \multicolumn{1}{|c|}{ Parameters } & Control & $\begin{array}{c}\text { Experiment } \\
\text { with Ni }\end{array}$ & $\begin{array}{c}\text { Experiment } \\
\text { with Mn }\end{array}$ & $\begin{array}{c}\text { Experiment } \\
\text { with Pb }\end{array}$ \\
\hline $\begin{array}{l}\text { Lobes of } \\
\text { hepatopancreas, } \\
\mu \mathrm{m}^{2}\end{array}$ & $3856.59 \pm 171.54$ & $3698.94 \pm 146.02$ & $3286.03 \pm 142.7^{*}$ & $3745.28 \pm 154.72$ \\
\hline $\begin{array}{l}\text { Hepatopancreas } \\
\text { lumen, } \mu \mathrm{m}^{2}\end{array}$ & $1155.62 \pm 62.02$ & $1046.93 \pm 99.56$ & $707.31 \pm 37.14^{*}$ & $648.9 \pm 42.35^{*}$ \\
\hline
\end{tabular}

Note: ${ }^{*}$ - difference significant at $\mathrm{p}<0.05$ 
Also, for all crustaceans in the experiment with manganese and lead, there was a significant decrease in the cross-sectional area of the hepatopancreas lumen by $38.79 \%$ and $43.85 \%$ respectively.

Investigation of hepatopancreas of marbled crayfish showed changes in the histological structure of the tissue (Fig. 3).

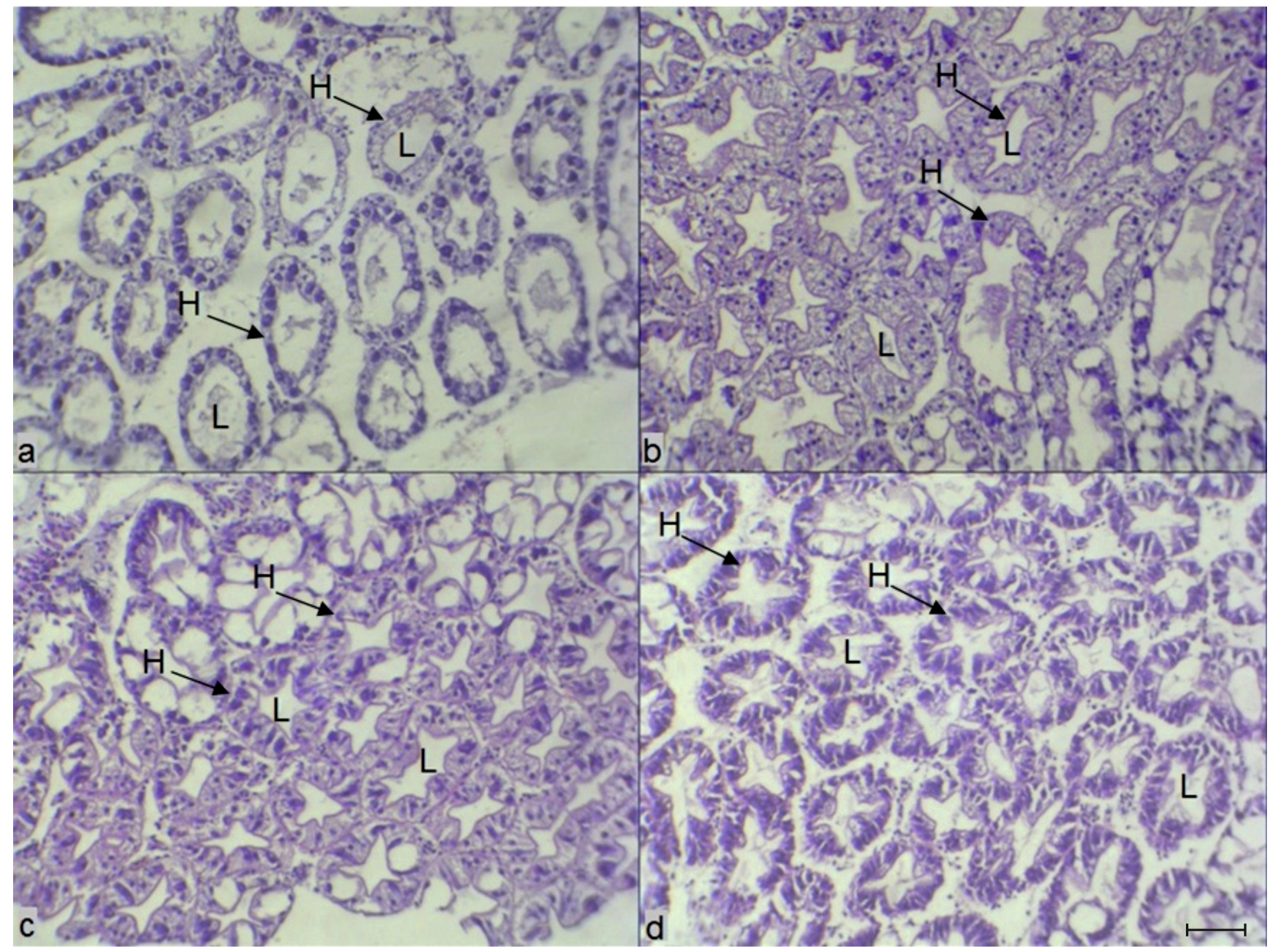

Figure 3. Hepatopancreas of marbled crayfish, tubules in cross-section: a - experiment with nickel; b- experiment with manganese; $\mathrm{c}$ - experiment with lead; d-control; $\mathrm{H}$ - Lobes of hepatopancreas,

$\mathrm{L}$ - Hepatopancreas lumen; bar - $10 \mu \mathrm{m}$

Heavy metals influenced the shape of the hepatopancreas lobes and the size of the lumen of the gland. Ions of nickel, manganese and lead caused deformation of the adenic part of the gland and excretory ducts.

Physiological evaluation of fat cells under the influence of heavy metals. The adipose tissue is a kind of connective tissue. Almost all of the fat cell, the specific function of which is the accumulation and exchange of lipids, is filled with a fat drop that surrounds the cytoplasm with displacement of the nucleus at the periphery (Fig. 4). The main physiological significance of adipose tissue is that it carries the function of the energy depot of the body. 


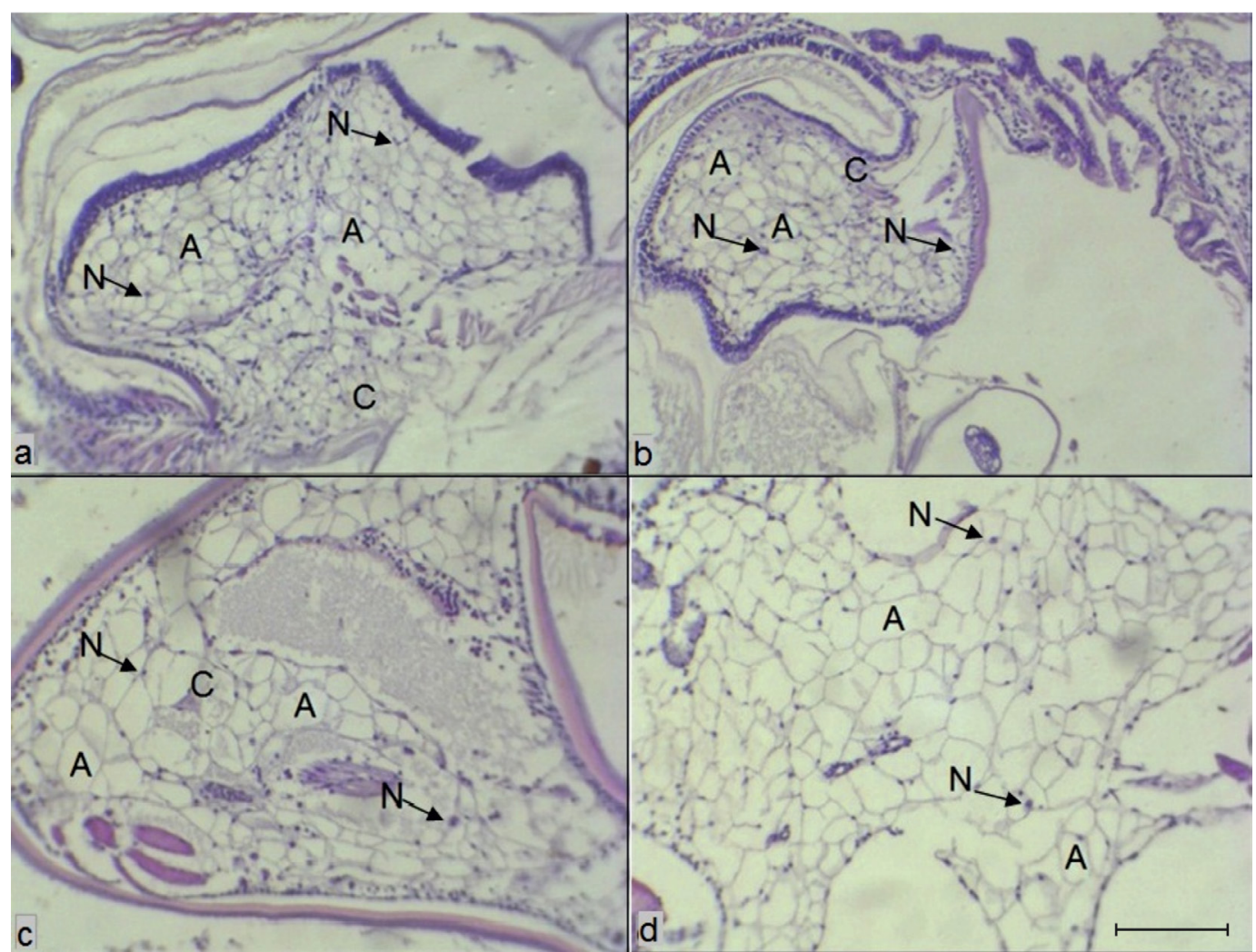

Figure 4. Adipocytes of $P$. virginalis (Lyko, 2017): a - experiment with nickel; b- experiment with manganese; $\mathrm{c}$ - experiment with lead; d-control; A - Adipocyte cell, $\mathrm{N}$ - nucleus; bar - $50 \mu \mathrm{m}$

Investigation of adipocytes of connective tissue showed a significant difference between cell sizes under the influence of heavy metals. Dimensions of adipocytes fluctuated in a wide range from $144 \mu^{2}$ to $537 \mu \mathrm{m}^{2}$. In control, the adipocyte area was $406.96 \mu \mathrm{m}^{2}$ (Table 3).

Table 3. Histometric parameters of fat cells of $P$. virginalis (Lyko, 2017) $(n=50, x \pm$ SD)

\begin{tabular}{|c|c|c|c|c|}
\hline Parameters & Control & $\begin{array}{c}\text { Experiment } \\
\text { with Ni }\end{array}$ & $\begin{array}{c}\text { Experiment } \\
\text { with } \mathrm{Mn}\end{array}$ & $\begin{array}{c}\text { Experiment } \\
\text { with } \mathrm{Pb}\end{array}$ \\
\hline Adipocyte area, $\mu \mathrm{m}^{2}$ & $406.96 \pm 21.64$ & $194.88 \pm 9.81^{*}$ & $144.13 \pm 8.01 *$ & $537.11 \pm 31.6^{*}$ \\
\hline
\end{tabular}

Note: ${ }^{*}$ - difference significant at $\mathrm{p}<0.05$

A significant reduction by 2.1 times and 2.8 times respectively was noted for experimental groups with nickel and manganese. In the experiment with lead, an increase in the area of adipocytes was 1.3 times.

Physiological assessment of hemolymphs under the influence of heavy metals. The composition of the formed elements and chemicals in hemolymph, its $\mathrm{pH}$, vary depending on the development of crayfish and the influence of the environment, are indicators of the physiological state.

According to the results of studies, it was found that under conditions of exposure to lead ions there is a significant increase in the area of blast (1.4 times). In the control group of marbled crayfish, the blast area was $110.52 \pm 27.49 \mu \mathrm{m}^{2}$, after the influence of lead ions for 21 days the blast area was set at $156.36 \pm 47.95 \mu \mathrm{m}^{2}$ (Fig. 5). 


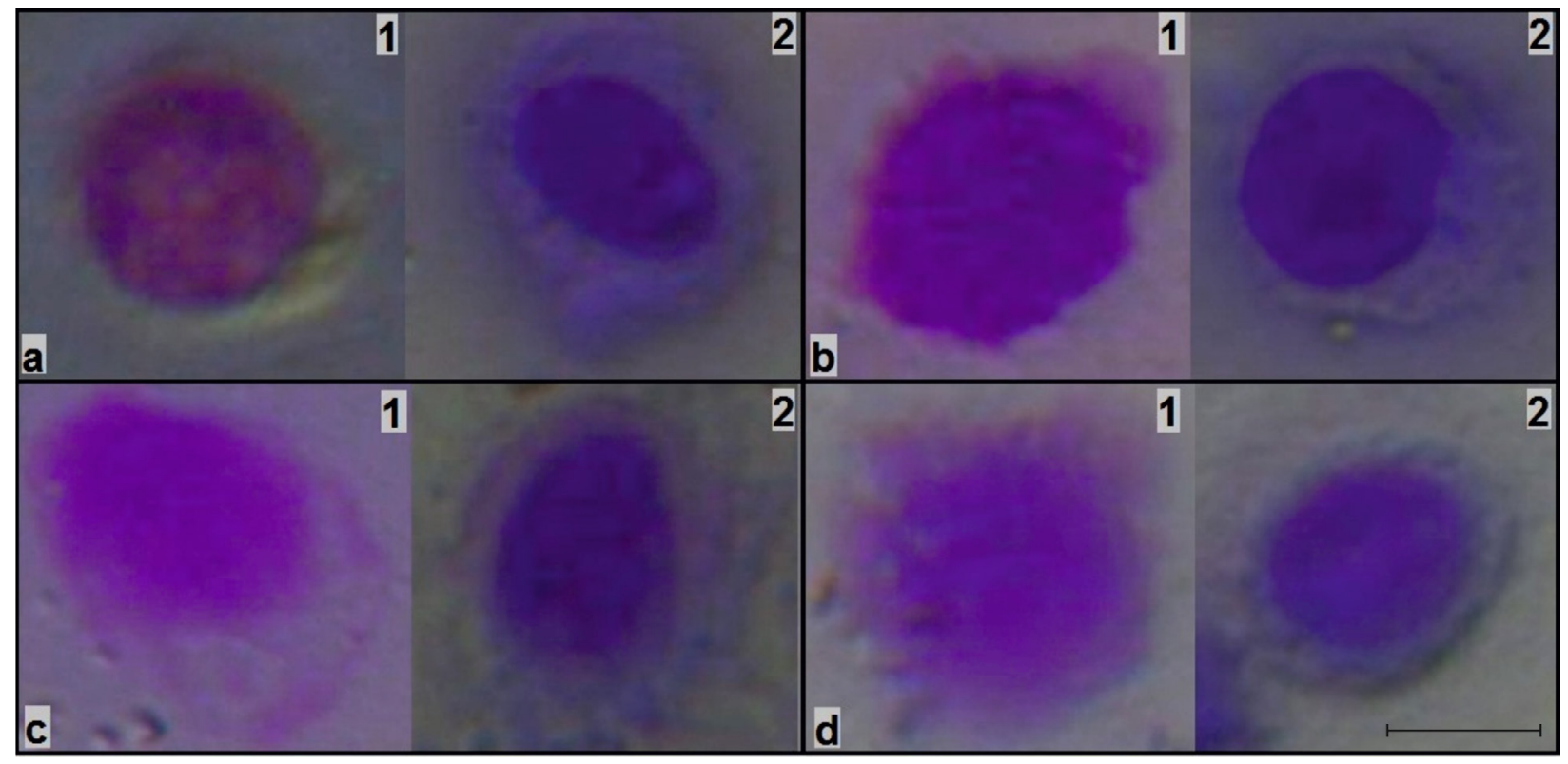

Figure 5. Hemolymph cells of $P$. virginalis (Lyko, 2017): 1 - control; 2 - experiment with manganese, 3 - experiment with lead, 4 - experiment with nickel, 1 - blast, 2 - round hyalineocyte; bar $-10 \mu \mathrm{m}$

In studies with the manganese and nickel there was no significant decrease in cells. Blast area under the influence of manganese is $108.26 \pm 53.79 \mu \mathrm{m}^{2}$, under the influence of nickel it is $103.32 \pm 38.38 \mu \mathrm{m}^{2}$ (Table 4).

Table 4. Area of hemolymph cells of marbled crayfish, $\mathrm{M} \pm \mathrm{SD} \mu \mathrm{m}^{2}$

\begin{tabular}{|l|c|c|c|c|}
\hline Cell types & $\begin{array}{c}\text { Experiment } \\
\text { with Ni }\end{array}$ & $\begin{array}{c}\text { Experiment } \\
\text { with } \mathrm{Mn}\end{array}$ & $\begin{array}{c}\text { Experiment } \\
\text { with } \mathrm{Pb}\end{array}$ & $\begin{array}{c}\text { Experiment } \\
\text { with Ni }\end{array}$ \\
\hline Blast, $\mathrm{n}=35$ & $110.52 \pm 27.49$ & $108.26 \pm 53.76$ & $156.36 \pm 47.95^{* *}$ & $103.32 \pm 38.38$ \\
\hline $\begin{array}{l}\text { Round hyalineocyte, } \\
\mathrm{n}=15\end{array}$ & $170.63 \pm 32.46$ & $170.82 \pm 48.79$ & $154.64 \pm 71.92$ & $96.29 \pm 17.46^{* *}$ \\
\hline
\end{tabular}

Note: $* *$ - difference significant at $\mathrm{p}<0.01$.

Studying the blast sizes showed that under the influence of heavy metals, the size of blast in the control was $110 \mu \mathrm{m}^{2}$, there was a significant increase (1.4 times) of the blast area under the influence of lead ions up to $156 \mu \mathrm{m}^{2}$, and a decrease of cell sizes in the experiment with manganese and nickel was observed

While the area of round hyalinocytes in the control and in the experiment with manganese did not differ significantly and amounted to $170 \mu \mathrm{m}^{2}$, in the experiment with lead cells decreased by 1,1 times, and in the experiment with nickel decreased by 1.7 times.

In contrast to the blast area, the obtained data show that the area of round hyalinocytes in the control group and in the group with the added manganese did not differ significantly and was $170.63 \pm 32.46 \mu \mathrm{m}^{2}$ in the control group, $170.82 \pm 48.79 \mu^{2}$ under the influence of manganese. Under the influence of lead, the cells decreased by 1.1 times and reached $154.64 \pm 71.92 \mu \mathrm{m}^{2}$.

Experimental data show that the effect of nickel most of all resulted in a decrease in the area of round hyalineocytes (1.7 times) and under the influence of this metal the cell area was $96.29 \pm 17.46 \mu \mathrm{m}^{2}$.

\section{Conclusions}

During the study on hepatopancreas, it was experimentally determined that heavy metals had an effect on the structure of the lobes and the size of the lumen. In the experiment with manganese and lead, the hepatopancreas was reduced by $14.79 \%$ and $2.89 \%$, respectively, and a significant 
decrease, which reached $38.79 \%$ and $43.85 \%$ respectively was observed in the area of the cross section of the hepatopancreas lumen.

Studies on the size of adipocytes indicated a significant decrease in the experimental groups with nickel and manganese by 2.1 times and 2.8 times, respectively. In an experiment with lead, an increase in the area of adipocytes was 1.3 times.

Under the influence of lead ions there was a significant increase in the area of blast by 1.4 times; with the manganese and nickel there was no significant decrease in cells. While the area of round hyalinocytes in the control and in the experiment with manganese did not differ significantly, in the experiment with lead cells decreased by 1.1 times, and in the experiment with nickel by 1.7 times.

\section{Conflict of Interest}

The authors declare that there is no conflict of interest.

\section{References}

[1] G. Kotovska et al., East European crayfish stocks at risk: arrival of non-indigenous crayfish species, Knowl. Manag. Aquat. Ecosyst. 417 (2016) 37.

[2] O. Marenkov et al., Efect of zinc and cadmium ions on histostructure of antennal glands of marbled crayfish Procambarus fallax (Hagen, 1870) $f$. virginalis (Decapoda), Acta Biologica Universitatis Daugavpiliensis. 17(2) (2017) 219-224.

[3] K.K. Holoborodko et al., The problem of assessing the viability of invasive species in the conditions of the steppe zone of Ukraine, Visnyk of Dnipropetrovsk University Biology, Ecology. 24(2) (2016) 466-472.

[4] R.A. Novitsky, M.O. Son, The first records of Marmorkrebs [Procambarus fallax (Hagen, 1870) f. virginalis] (Crustacea, Decapoda, Cambaridae) in Ukraine, Ecologia Montenegrina. 5 (2016) 44-46.

[5] O.M. Marenkov et al., Impact of ions of zinc and cadmium on body weight, fertility and condition of the tissues and organs of Procambarus virginalis (Decapoda, Cambaridae), Regulatory Mechanisms in Biosystems. 8(4) (2017) 628-632.

[6] O. Marenkov et al., Parameters of the histological adaptation of Marmorkrebs Procambarus fallax f. virginal (Decapoda, Cambaridae) to zinc and cadmium ions pollution, World Scientific News. 90 (2017) 189-202.

[7] O.V. Fedonenko et al., The current problems of hydrobiology: Zaporizke Reservoir, LIRA, Dnipropetrovsk, Ukraine, 2012. (in Ukrainian)

[8] O.V. Fedonenko, T.S. Sharamok, Environmental assessment of key areas of Zaporizhzhya Reservoir fisheries (Ukraine), Ecologicheskiy vestnik Severnogo Kavkaza. 11 (2015) 45-50.

[9] O. Fedonenko et al., Fishery and environmental situation assessment of water bodies in the Dnipropetrovsk region of Ukraine [Monograph], World Scientific News. 98(1) (2018) 11-15.

[10] O. Fedonenko, N. Esipova, T. Sharamok, The accumulation of heavy metals and cytometric characteristics of red blood cells in different ages of carp fish from the Zaporozhian Reservoir, International Letters of Natural Sciences. 53 (2016) 72-79.

[11] Yu.M. Sitnik, N.V. Bren, The content of heavy metals in the organs and tissues of the river crawfish of the Kilia Delta of the Danube, Fish Farming. 48 (1994) 85. (in Ukrainian)

[12] J.V. Mur, S. Ramamurthy, Heavy metals in natural waters, Mir, Moscow, USSR, 1987. (in Russian) 
[13] G.A. Leonova et al., Toxic effect of lead compounds on hydrobionts and waterfowl: A survey, Hydrobiol. Journal. 28(4) (1992) 68-71. (in Russian)

[14] A.I. Dvoretsky, F.P. Ryabov, Zaporozhye (Dnieper) Reservoir: Information handbook, Dnipropetrovsk, Ukraine, 2001. (in Russian)

[15] V.D. Romanenko, Fundamentals of hydroecology, Oberegi, Kiev, Ukraine, 2001. (in Ukrainian)

[16] Spravochnik po gidrokhimii (Hydrochemistry Manual), A.M. Nikanorov (Ed.), Gidrometeoizdat, Leningrad, USSR, 1989. (in Russian)

[17] J.D. Shields, R. Boyd, Atlas of lobster anatomy and histology, Virginia Institute of Marine Science, Gloucester Point, 2014.

[18] Medical ethics and human rights: the provisions for the use of animals in biomedical experiments, Exp. Clin. Physiol. Biochem. 22(2) (2003) 108-109. (in Ukrainian) 